\title{
Abundance Detection and Molecular Characterization of Toxoplasma gondii by SAG 1 Gene in Rodents and Cattle of Golestan Province, Northeast of Iran
}

Javid Sadraie and Ehsan Shariat Bahadory*

Medical University of Tarbiat Modaress, Tehran, Iran

\begin{abstract}
Background: Toxoplasma parasite is from Toxoplasmatidea family that initially was seen in ctinodactylus gondii rodent. Toxoplasma parasites that extracted from different rodents are same in immunologic and morphologic characteristics but have differences in pathogenicity and genotypes in mice. The rodents and cattle are most reservoir hosts in environment that by attention of human environment vicinity to cattle and rodent's environment causes Toxoplasma dispersion in that area. The aim of this study was Molecular detection of Toxoplasma gondii in rodents and cattle of Golestan province, northeast of Iran.
\end{abstract}

Materials and methods: In this study we collected 285 mice and 185 cattle tissues from Golestan forest and extracted brains of rodents and hearts tissues of cattle to obtain DNA from these tissues. We divided these rodents to 4 groups and then detected the positive samples by PCR method.

Results: In this study we found 68 samples of these rodents were positive for SAG1 gene. 38 samples were Ratus ratus, 10 samples were Ratus norvegicus, 10 samples were Mus musculus and 10 samples were Rombumys opimus. Also 81 samples of cattle hearts were positive for SAG1 gene.

Conclusion and discussion: in this study we found that the different types of rodents were responsible to spread of toxoplasmosis, also SAG1 gene was very useful marker to detect toxoplasmosis in rodents of northeast area of Iran. Also in this area the numbers of toxoplasmosis cattle were in very high range.

Keywords: Toxoplasmosis; SAG1 gene; PCR; Golestan forest; Rodents; Cattle

\section{Introduction}

Toxoplasma gondii is an intracellular parasite that infected many hosts in Iran, including human, rodents, cats and domestic animals. Because domestic and feral cats are the natural definitive host, they play an important role in disseminating of toxoplasmosis [1-5]. Rodents are very important reservoir in dissemination of toxoplasmosis in Iran. The brain of rodents and the heart of cattle are the most important tissues that can infect by toxoplasmosis. Toxoplasmosis infection causes tissue cysts in these organs of rodents and cattle. The major gene that extracted from these organs to detect toxoplasmosis is SAG1 gene [5-10].

Toxoplasmosis infection pathway is eating of infected tissues from rodents by cats or uncooked meats from domestic animals to human, then laying Oocysts from cats in environments to dissemination of infection to human or domestic animals. The major disease of this parasite in human is encephalitis or brain disorders [11-13]. Primary routes of acute human $T$. gondii infection include ingestion of tissue cysts in undercooked, contaminated meat, congenital infection through the placenta, and ingestion of Oocysts from soil, water, or cat litter. Oocysts are shed in cat feces and can remain viable in soil and water samples for months to years. The infected rodents are the main food for cats, and this cycle is the important cause of spreading toxoplasmosis infection. My purpose was the abundance detection of toxoplasmosis in rodents and cattle of Golestan province using SAG1 gene in brain and heart tissues [14-18].

\section{Materials and Methods}

Different regions of Golestan province have different climate and are notably heterogeneous. Northern parts are located in the arid and semi-arid climate, southern parts show a mountainous climate, and central and southern west parts have a moderate Mediterranean climate (Weather Centre Hashem). 185 cattle were collected from 20 villages of 5 towns locating in different climates of Golestan province. Also rodents were collected from Golestan forest. This study was done on March to September 2016. Because of this study was based on molecular detection; we did not use other examinations for example histopathology examinations.

\section{Preparation of samples}

We collected 285 mice from Golestan forest and 185 cattle hearts from 20 villages. Then brains and hearts of mice and cattle were removed. These organs were fixed in $95 \%$ Ethanol, and preserved in $4^{\circ} \mathrm{C}$ until DNA extraction. These rodents divided in 4 groups: (Rattus rattus, Rattus norvegicus, Mus musculus and Rombomys opimus) (Table 1).

\section{DNA extraction}

To extraction genomic DNA, we cut approximately $3 \mathrm{~g}$ of brain and heart tissues by DNG/proteinase $\mathrm{K}$ method from Sinacolon company and eluted into $50 \mu \mathrm{DDH} 2 \mathrm{O}$ according to the manufacturer's

*Corresponding author: Ehsan Shariat Bahadory, PhD of Medical Parasitology, Medical University of Tarbiat Modaress, Tehran, Iran, Tel: 0098912418960; E-mail: ehsanshariat63@gmail.com

Received April 22, 2017; Accepted June 12, 2017; Published June 14, 2017

Citation: Sadraie J, Bahadory ES (2017) Abundance Detection and Molecular Characterization of Toxoplasma gondii by SAG1 Gene in Rodents and Cattle of Golestan Province, Northeast of Iran. J Vet Sci Technol 8: 446. doi: 76749170.0014516

Copyright: ( 2017 Sadraie J, et al. This is an open-access article distributed under the terms of the Creative Commons Attribution License, which permits unrestricted use, distribution, and reproduction in any medium, provided the original author and source are credited. 
Citation: Sadraie J, Bahadory ES (2017) Abundance Detection and Molecular Characterization of Toxoplasma gondii by SAG1 Gene in Rodents and Cattle of Golestan Province, Northeast of Iran. J Vet Sci Technol 8: 446. doi: 10.4172/2157-7579.1000446

Page 2 of 5

\begin{tabular}{|c|c|}
\hline Rodents type & Numbers \\
\hline Rattus rattus & 130 \\
\hline Rattus norvegicus & 45 \\
\hline Mus musculus & 60 \\
\hline Rombomys opimus & 50 \\
\hline
\end{tabular}

Table 1: The total samples of rodents divided in 4 groups [14-18].

recommendations. A PCR targeting the T. gondii SAG1 gene was performed to detect possible infection with T. gondii. DNA samples giving positive SAG1 amplification were then used for genetic characterization.

We cut $3 \mathrm{~g}$ of tissue into small places and placed the samples into a $1.5 \mathrm{ml}$ sterile tube. Then added $180 \mu \mathrm{l}$ (microliter) lyse buffer (pepsin) to homogenization and 400 microliter (DNG/proteinase $\mathrm{K}$ ) and then homogenized the samples. If the sample size was larger than $3 \mathrm{~g}$ we should increase the amount of lyse buffer proportionally.

Added $20 \mu \mathrm{l}$ proteinase $\mathrm{K}$ to the samples. Then mixed immediately by shaking for 20 seconds. Then incubated at $60^{\circ} \mathrm{C}$ for 1 hour to lyse samples. If tissue was difficult to lyse, we increased the incubation time to 2-3 hours. Then inverted the samples every 10-15 minutes. Then we added 300 microliter isopropanol to DNA precipitation. After 5-10 minutes we washed the tubes by $70 \%$ ethanol and finally we eluted the DNA by DDH20. The eluted DNA preserved in $-20^{\circ} \mathrm{C}$ freezer until using PCR method to detection of infection. The purification of DNA was done with Nanodrop instrument.

\section{PCR analysis for T. gondii SAG1 gene}

To genetically identify the presence of KI-1 Tachyzoites in visceral organs, PCR analysis was performed to detect Toxoplasma SAG1 gene as a diagnostic gene. DNA extraction was performed using the DNeasy ${ }^{\circ}$ Tissue kit (DNG Sinacolon). The primers were designed by BLAST method from NCBI site and produced by Pishgam Company.

Primer sequences were:

5' - GCTGTAACATTGAGCTCCTTGASTTCCTG-3' for forward and

\section{5' - CCGGAACAGTACTGATTGTTGTCTTGAG-3' for reverse}

Amplification of the SAG1 gene was completed in the following conditions: 1 cycle of $5 \mathrm{~min}$ at $95^{\circ} \mathrm{C}$ for initial denaturation followed by 30 cycles of $1 \mathrm{~min}$ at $95^{\circ} \mathrm{C}, 1 \mathrm{~min}$ at $62^{\circ} \mathrm{C}$, and $3 \mathrm{~min}$ at $74^{\circ} \mathrm{C}$. The best annealing temperature was $62^{\circ} \mathrm{C}$. Amplification was performed using a DNA thermal cycler (Eppendorf instrument). PCR amplification products were examined in $1.5 \%$ agarose gels and confirmed by staining with Safe stain and visualized under Gel Doc using UV. The statistical surveys were done with SPSS 18 software (Table 2).

\section{Results}

In this study we found 68 samples of these rodents were positive for SAG1 gene. 38 samples were Ratus ratus, 10 samples were Ratus norvegicus, 10 samples were Mus musculus and 10 samples were Rombumys opimus. The samples were positive in $1180 \mathrm{bp}$ location. Also 81 heart samples of cattle were positive for SAG1 gene. Toxoplasma gondii SAG1 gene after NCBI blast, complete cds (Table 3; Figures 1 and 2).

\section{Origin:}

1 acaatgtgca cctgtaggaa gctgtagtca ctgctgattc tcactgttct cggcaagggc

61 cgacgaccgg agtacagttt ttgtgggcag agccgttgtg cagctttccg ttgttctcgg

\begin{tabular}{|c|c|c|}
\hline Materials & Volume & Final concentration \\
\hline Master Mix & $7.5 \mu \mathrm{l}$ & $2 \mathrm{X}$ \\
\hline DNA Sample & $2 \mu \mathrm{l}$ & $10-100 \mathrm{ng} / \mu \mathrm{l}$ \\
\hline Work Primer & $1 \mu \mathrm{l}$ & $20 \mathrm{pmol}$ \\
\hline Distilled water & $4.5 \mu \mathrm{l}$ & - \\
\hline Total & $15.0 \mu \mathrm{l}$ & - \\
\hline
\end{tabular}

Table 2: PCR substrates [14-18].

\begin{tabular}{|c|c|c|}
\hline Rodents type & Numbers & Numbers of positive \\
\hline Rattus rattus & 130 & 38 \\
\hline Rattus norvegicus & 45 & 10 \\
\hline Mus musculus & 60 & 10 \\
\hline Rombomys opimus & 50 & 10 \\
\hline
\end{tabular}

Table 3: Total samples and positive samples for SAG1 gene [14-18].

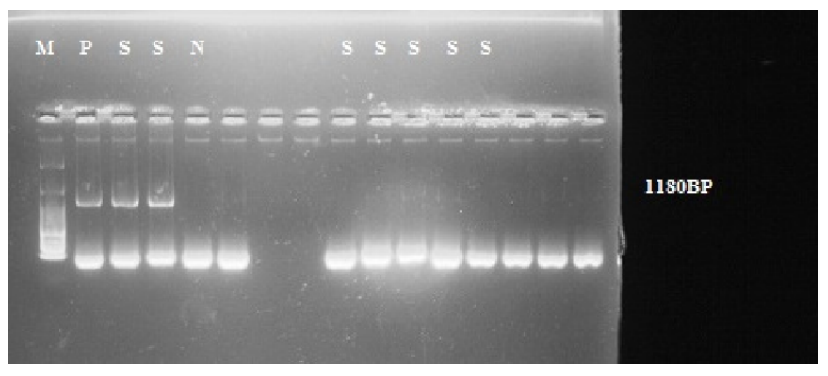

Figure 1: PCR conclusion for SAG1 gene. P: Positive control. M: Size marker. S: Sample. N: Negative control [14-18].

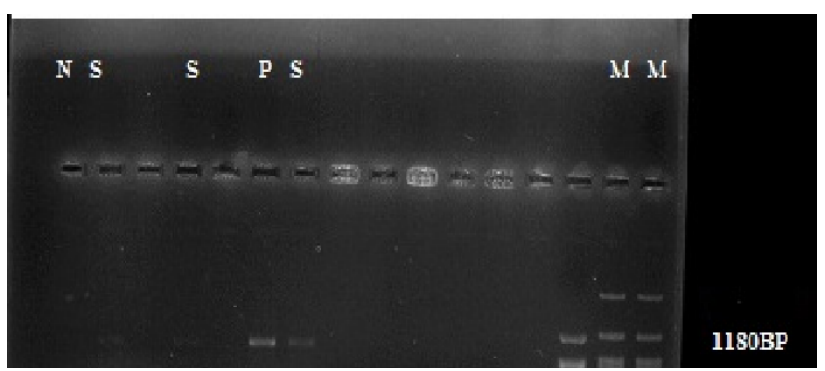

Figure 2: PCR conclusion for SAG1 gene. P: Positive control. M: Size marker. S: Sample. N: Negative control [14-18]

121 ttgtgtcaca tgtgtcattg tcgtgtaaac acacggttgt atgtcggttt cgctgcacca $181 \mathrm{cttcattatt} \mathrm{tcttctggtt} \mathrm{ttttgacgag} \mathrm{tatgtttccg} \mathrm{aaggcagtga} \mathrm{gacgcgccgt}$

241 cacggcaggg gtgtttgecg cgcccacact gatgtcgttc ttgcgatgtg gegttatggc 301 atcggatccc cctcttgttg ccaatcaagt tgtcacctgc ccagataaaa aatcgacagc

361 cgcggtcatt ctcacaccga cggagaacca cttcactctc aagtgcccta aaacagcgct

421 cacagagcct cccactcttg cgtactcacc caacaggcaa atctgcccag cgggtactac

481 aagtagctgt acatcaaagg ctgtaacatt gagctccttg attcctgaag cagaagatag

541 ctggtggacg ggggattctg ctagtctcga cacggcaggc atcaaactca cagttccaat

601 cgagaagttc cccgtgacaa cgcagacgtt tgtggtcggt tgcatcaagg gagacgacgc 
Citation: Sadraie J, Bahadory ES (2017) Abundance Detection and Molecular Characterization of Toxoplasma gondii by SAG1 Gene in Rodents and Cattle of Golestan Province, Northeast of Iran. J Vet Sci Technol 8: 446. doi: 10.4172/2157-7579.1000446

Page 3 of 5

661 acagagttgt atggtcacag tgacagtaca agccagagcc tcatcggtcg tcaataatgt

721 cgcaaggtgc tcctacggtg cagacagcac tcttggtcct gtcaagttgt ctgcggaagg

781 acccactaca atgaccctcg tgtgcgggaa agatggagtc aaagttcctc aagacaacaa

841 tcagtactgt tccgggacga cgctgactgg ttgcaacgag aaatcgttca aagatatttt

901 gccaaaatta actgagaacc cgtggcaggg taacgcttcg agtgataagg gtgccacgct

961 aacgatcaag aaggaagcat ttccagccga gtcaaaaagc gtcattattg gatgcacagg

1021 gggatcgcct gagaagcatc actgtaccgt gaaactggag tttgccgggg ctgcagggtc

1081 agcaaaatcg gctgcgggaa cagccagtca cgtttccatt cttgccatgg tgatcggact

\section{1 tattggctct atcgcagctt gtgtcgcgtg agtgattacc gttgtgc}

These results showed that positive samples in $1180 \mathrm{bp}$ location by SAG1 gene. These results obtained from GelDock instrument. Primer designation was done by BLAST software from NCBI site. In 130 samples from Rattus rattus 38 samples were positive, in 45 samples from Rattus norvegicus 10 samples were positives, in 60 samples from Mus musculus 10 samples were positive and finally in 50 samples from Rombomys opimus 10 samples were positives. Also 81 samples of heart tissues of cattle were positive for toxoplasmosis.

Figure 3 showed that $1=$ Rattus rattus, $2=$ Rattus norvegicus, $3=M u s$ musculus and $4=$ Rombomys opimus. Series 1 (blue) were total sample and series 2 (red) were positive samples. Positive samples bands detected on 1180 bp region [14-18]. These results obtained from GelDock instrument (Figure 4). Figure 5 showed that in the 185 heart tissues of cattle, 85 samples were positive for Toxoplasma SAG1 gene.

\section{Discussion}

Regarding to free living of rodents, cattle and also presence of them in large number in rural areas, obtaining data about $T$. gondii dynamic in rodents and cattle' population of rural area is critical for the establishment of monitoring programs [19-21]. My purpose of this study was abundance detection of toxoplasmosis in rodents and cattle of Golestan province using SAG1 gene. Toxoplasmosis is a zoonosis infection between rodents, cats, human and domestic animals. Rodents are main reservoir host for toxoplasmosis to infect feral cats and uncooked meat of domestic animals such as cattle or sheep can transfer toxoplasmosis to human. In both ways the human can plague with toxoplasmosis. In Golestan province, the population of rodents is higher than cattle but both animals have same role in spreading of toxoplasmosis. Climate characteristic of Golestan province is optimum for dissemination of toxoplasmosis. Prevalence of $40 \% T$. gondii antibodies in stray cats in Sari, Northern Iran, has been reported by Sharif et al. They also survey anti $T$. gondii antibodies with latex agglutination test (LAT) on 100 serum samples collected from stray cats in five urban areas of Sari. Sari is located near Golestan province in North Iran and has humid climate which has been introduced suitable for $T$. gondii growth [22-25]. A study in Tabriz by Jamali clarified $36 / 2 \% T$. gondii infection of cats by using dye test that differed with our methods. In this study most positive sampled has been belonged to Azadshahr villages and also Gorgan villages. Compare to Bandar-Turkmen,

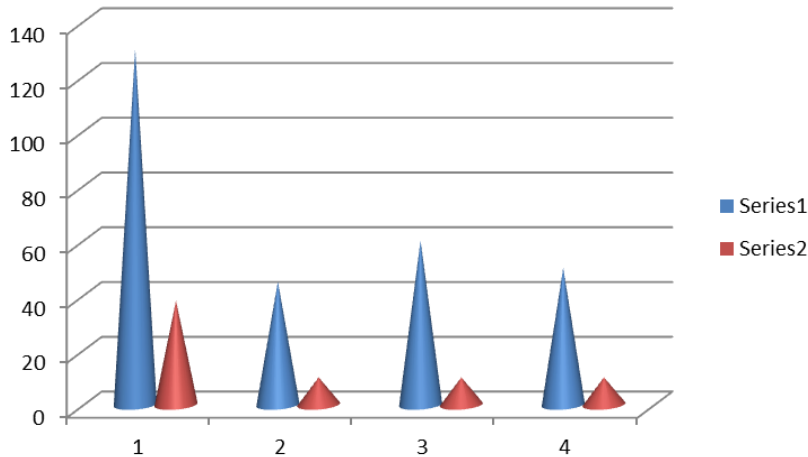

Figure 3: Positive samples from toxoplasmosis rodents [14-18].

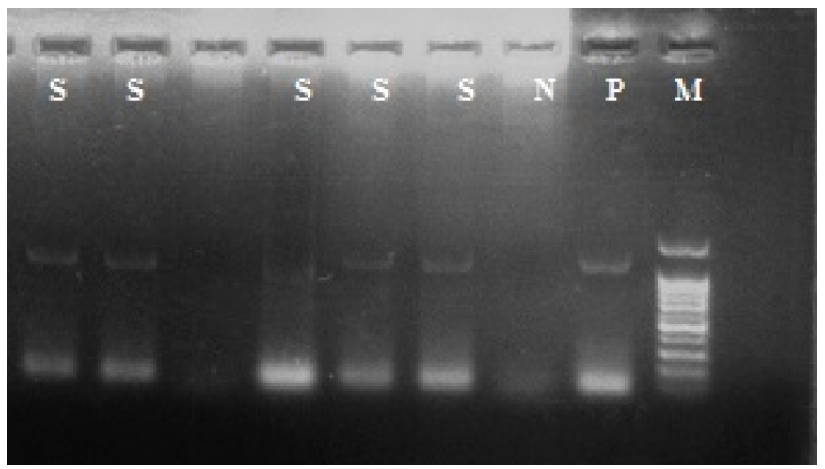

Figure 4: Positive samples of cattle heart tissues. M: Size marker. S: Samples. N: Negative control. P: Positive control.

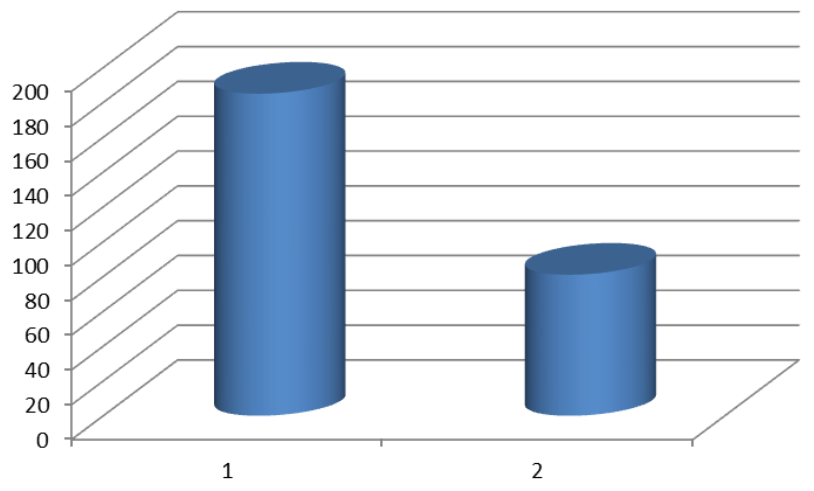

Figure 5: 1=Total heart samples of cattle. 2=Number of positives for toxoplasmosis cattle [14-18].

Gonbad and Aghghala that have semi-arid and arid climates, these two regions have humid climate. So detection of higher positive sample in Azadshahr villages and also Gorgan villages can be due to more suitable condition for growth of T. gondii oocyst in these areas. Also Mostafavi et al. reported highest prevalence of human toxoplasmosis, 70\%, in humid regions of North Iran. Prevalence of Toxoplasma gondii antibodies in cats from Urmia, Northwest of Iran. In Sari by contrast, differences in T. gondii infection were detected between male stray cats and female stray cats. In 2013, Cong detected house sparrows toxoplasmosis in China, Khademvatan detected birds toxoplasmosis in southwest of Iran and Ortega found pigs toxoplasmosis in Mexico [22-26]. Most of the 
studies didn't reported significant different in T. gondii infection of two sexes and the role of sexuality in T. gondii exposure is not clear. In recent years had not any studies in rodents toxoplasmosis in Golestan area. In 2011, Hong did very important study in genotyping of cat's toxoplasmosis. In 2011, Dubey done a study in genotyping of zoonosis toxoplasmosis in USA. In 2012, Selseleh did a study in genotyping of Tehran rodent's toxoplasmosis by SAG1 gene. In 2012, Habibi did very important study in detection of sheep toxoplasmosis by SAG1 gene. In 2013, Ling jang did immense study in detection of rodent toxoplasmosis by SAG1 gene in china. In 2013, Cabral did a study in detection of rodent toxoplasmosis in Brazil. In 2014, Barros et al. had found genetic characteristics of Toxoplasma gondii from doves in Brazil. In 2014, Yan et al. found genetic characteristics of Toxoplasma gondii from rodents in china. In 2014, Gjerede et al. had found genetic characteristics of Toxoplasma gondii from muscles of Lutra in Norway. In 2014, Chen et al. detected Toxoplasma gondii from HIV positive people in China [26-30]. In recent years have not perform any studies to detect rodents and cattle toxoplasmosis at the same time in Golestan area. This study showed important role of rodents and cattle in dissemination of toxoplasmosis in humid area. In this study we showed that the SAG1 gene was very important marker to detection of abundance of zoonotic toxoplasmosis and brain or heart tissue was main tissues to follow SAG1 gene from Tachyzoites of Toxoplasma parasite, also the rodents and cattle were very important reservoirs in dissemination of toxoplasmosis to human in Golestan area, northeast of Iran [26-30].

\section{Conclusion}

In this study we concluded: The northeast of Iran was very important region for following toxoplasmosis infection, specifically in animals such as rodents and cattle. In other study that had done four month after this surveillance, we found that the dominant genotype of Toxoplasma gondii in that area was genotype using PCR-RFLP by HaeII restriction enzyme.

\section{Acknowledgements}

The current research was funded by Tarbiat Modaress University.

\section{References}

1. Evers F, Garcia JL, Navarro IT, Zulpo DL, Nino BS, et al. (2013) Diagnosis and isolation of Toxoplasma gondii in horses from Brazilian slaughterhouses. Rev Bras Parasitol Vet 22: 58-63.

2. Quan JH, Zhou W, Cha GH, Choi IW, Shin DW, et al. (2013) Kinetics of IL-23 and IL-12 secretion in response to Toxoplasma gondii antigens from THP-1 monocytic cells. Korean J Parasitol 51: 85-92.

3. Dubey JP, Hill D, Zarlenga D, Choudhary S, Ferreira LR, et al. (2013) Isolation and characterization of new genetic types of Toxoplasma gondii and prevalence of Trichinella murrelli from black bear (Ursus americanus). Vet Parasitol 196: 24-30.

4. Assmar M, Yassaei F, Terhovanesian A, Esmaeili AR, Nahrevanian $\mathrm{H}$, et al (2004) Prenatal Diagnosis of Congenital Toxoplasmosis Validity of PCR Using Amniotic Fluid against Indirect Fluorescent antibody assay in mothers. Iranian J Public Health 33: 1-4

5. Pena HF, Vitaliano SN, Beltrame MA, Pereira FE, Gennari SM, et al. (2013) PCR-RFLP genotyping of Toxoplasma gondii from chickens from Espírito Santo state, Southeast region, Brazil: new genotypes and a new SAG3 marker allele. Vet Parasitol 192: 111-117.

6. Quan JH, Kim TY, Choi UI, Lee YH (2008) Genotyping of a Korean isolate of Toxoplasma gondii by multilocus PCR-RFLP and microsatellite analysis. Korean J Parasitol 46: 105-108.

7. Hong SH, Jeong YI, Kim JY, Cho SH, Lee WJ, et al. (2013) Prevalence of Toxoplasma gondii infection in household cats in Korea and risk factors. Korean J Parasitol 51: 357-361.

8. Dubey JP, Randall AR, Choudhary S, Ferreira LR, Verma SK, et al. (2013)
Occurrence, isolation, and genetic characterization of Toxoplasma gondii from white-tailed deer (Odocoileus virginianus) in New Jersey. J Parasitol 99: 763-769.

9. Selseleh M, Modarressi MH, Mohebali M, Shojaee S, Eshragian MR, et al (2012) Real-time RT-PCR on SAG1 and BAG1 gene expression during stage conversion in immunosuppressed mice infected with Toxoplasma gondii Tehran strain. Korean J Parasitol 50: 199-205.

10. Habibi G, Imani A, Gholami M, Hablolvarid M, Behroozikhah A, et al. (2012) Detection and Identification of Toxoplasma gondii Type One Infection in Sheep Aborted Fetuses in Qazvin Province of Iran. Iran J Parasitol 7: 64-72.

11. Selseleh MM, Keshavarz $H$, Mohebali M, Shojaee S, Modarressi M, et al. (2012) Production and Evaluation of Toxoplasma gondii Recombinant Surface Antigen 1 (SAG1) for Serodiagnosis of Acute and Chronic Toxoplasma Infection in Human Sera. Iran J Parasitol 7: 1-9.

12. Lim H, Lee SE, Jung BK, Kim MK, Lee MY, et al. (2012) Serologic survey of toxoplasmosis in Seoul and Jeju-do, and a brief review of its seroprevalence in Korea. Korean J Parasitol 50: 287-293.

13. Lee SE, Hong SH, Lee SH, Jeong YI, Lim SJ, et al. (2012) Detection of ocular Toxoplasma gondii infection in chronic irregular recurrent uveitis by PCR Korean J Parasitol 50: 229-231.

14. El Behairy AM, Choudhary S, Ferreira LR, Kwok OC, Hilali M, et al. (2013) Genetic characterization of viable Toxoplasma gondii isolates from stray dogs from Giza, Egypt. Vet Parasitol 193: 25-29.

15. Edwards JF, Dubey JP (2013) Toxoplasma gondii abortion storm in sheep on a Texas farm and isolation of mouse virulent atypical genotype T. gondii from an aborted lamb from a chronically infected ewe. Vet Parasitol 192: 129-136.

16. Dubey JP, Choudhary S, Kwok OC, Ferreira LR, Oliveira S, et al. (2013) Isolation and genetic characterization of Toxoplasma gondii from mute swan (Cygnus olor) from the USA. Vet Parasitol 195: 42-46.

17. Herrmann DC, Wibbelt G, Götz M, Conraths FJ, Schares G (2013) Genetic characterisation of Toxoplasma gondii isolates from European beavers (Castor fiber) and European wildcats (Felis silvestris silvestris). Vet Parasitol 191: 108-111.

18. Lilly EL, Wortham CD (2013) High prevalence of Toxoplasma gondii oocys shedding in stray and pet cats (Felis catus) in Virginia, United States. Parasit Vectors 6: 266 .

19. Zhang XX, Lou ZZ, Huang SY, Zhou DH, Jia WZ, et al. (2013) Genetic characterization of Toxoplasma gondii from Qinghai vole, Plateau pika and Tibetan ground-tit on the Qinghai-Tibet Plateau, China. Parasit Vectors 6: 291

20. Cabral AD, Gama AR, Sodré MM, Savani ES, Galvão-Dias MA, et al. (2013) First isolation and genotyping of Toxoplasma gondii from bats (Mammalia: Chiroptera). Vet Parasitol 193: 100-104.

21. Mancianti F, Nardoni S, D'Ascenzi C, Pedonese F, Mugnaini L, et al. (2013) Seroprevalence, detection of DNA in blood and milk, and genotyping of Toxoplasma gondii in a goat population in Italy. Biomed Res Int 2013: 905326.

22. Ortega-Pacheco A, Acosta Viana KY, Guzmán-Marín E, Segura-Correa JC Alvarez-Fleites M, et al. (2013) Prevalence and risk factors of Toxoplasma gondii in fattening pigs farm from Yucatan, Mexico. Biomed Res Int 2013: 231497.

23. Galván-Ramírez ML, Sánchez-Orozco LV, Rodríguez LR, Rodríguez S, RoigMelo E, et al. (2013) Seroepidemiology of Toxoplasma gondii infection in drivers involved in road traffic accidents in the metropolitan area of Guadalajara, Jalisco, Mexico. Parasit Vectors 6: 294.

24. Shichao X, Chen Z, Lei H, Tongyao W, Liusong N, et al. (2013) DNA Detection of Toxoplasma gondii witha Magnetic Molecular Beacon Probe via CdTe@Ni Quantum Dots as Energy Donor. J Nanomater 2013: 473703.

25. Cong W, Huang SY, Zhou DH, Zhang XX, Zhang NZ, et al. (2013) Prevalence and genetic characterization of Toxoplasma gondii in house sparrows (Passer domesticus) in Lanzhou, China. Korean J Parasitol 51: 363-367.

26. Khademvatan S, Saki J, Yousefi E, Abdizadeh R (2013) Detection and genotyping of Toxoplasma gondii strains isolated from birds in the southwest of Iran. Br Poult Sci 54: 76-80.

27. Barros LD, Taroda A, Zulpo DL, Cunha IA, Sammi AS, et al. (2014) Genetic characterization of Toxoplasma gondii isolates from eared doves (Zenaida auriculata) in Brazil. Rev Bras Parasitol Vet 23: 443-448.

28. Yan C, Liang LJ, Zhang BB, Lou ZL, Zhang HF, et al. (2014) Prevalence and genotyping of Toxoplasma gondii in naturally-infected synanthropic rats (Rattus norvegicus) and mice (Mus musculus) in eastern China. Parasit Vectors 7: 591 
Citation: Sadraie J, Bahadory ES (2017) Abundance Detection and Molecular Characterization of Toxoplasma gondii by SAG1 Gene in Rodents and Cattle of Golestan Province, Northeast of Iran. J Vet Sci Technol 8: 446. doi: 10.4172/2157-7579.1000446

Page 5 of 5

29. Gjerde B, Josefsen TD (2014) Molecular characterisation of Sarcocystis lutrae n. sp. and Toxoplasma gondii from the musculature of two Eurasian otters (Lutra lutra) in Norway. Parasitol Res 114: 873-886.
30. Chen LJ, Jia YX, Leng L, Luo M, Gao J, et al. (2014) Comparation of Toxoplasma gondii separated from HIV-positive people and RH strain GRA6 gene. Zhongguo Xue Xi Chong Bing Fang Zhi Za Zhi 26: 434-436. 